\title{
The Correlation of Tumor Budding Index with Histopathological Grading in Endometrial Cancer at the Department of Anatomic Pathology Faculty of Medicine Universitas Sumatera Utara / H. Adam Malik Hospital Medan
}

\author{
Devi Nafilah Yuzar, Betty, Jessy Chrestella, Soekimin, Joko S. \\ Lukito \\ Department of Anatomical Pathology, Faculty of Medicine,Universitas \\ Sumatera Utara, Medan, Indonesia. \\ devinafilah@yahoo.co.id
}

\begin{abstract}
Background: Endometrial cancer is the most common gynaecological malignancy with an increasing incidence. The survival rate is related to the histological type of the tumor including grading histology. Tumor budding is defined as single cells or clusters of up to four cells at the margin of the tumor front. This phenomenon is regarded as a histological basis of metastasis formation and further tumor invasion.

Methods: This is an analytical study with cross sectional approach on 38 resection specimens from the patients diagnosed as endometrial cancer stained with Hematoxylin \& Eosin. The statistical analysis was performed by using Chisquare test to analyze the correlation of tumor budding index and histological grading in endometrial cancer.

Results: The identification of 38 samples of endometrial cancer patients found that the mean age of the patients was 55,5 years with a minimum age of 31 years and a maximum age of 84 years, the most common age group was $>55$ years $(52,6 \%)$, the most frequent distribution was low budding $(57,9 \%)$, low histopathological grading $(68,4 \%)$, and there was a significant correlation between the tumor budding index and the histopathological grading $(\mathrm{p}=0,002)$.
\end{abstract}

Keyword : endometrial cancer, histopathological grading, tumor budding

\section{INTRODUCTION}

Endometrial cancer is a gynecological malignancy with an increasing incidence. ${ }^{1}$ According to GLOBOCAN statistics, it is estimated that there were 382,069 new cases and 89,929 deaths due to endometrial cancer in worldwide at 2018. In addition, endometrial cancer is the fourth most common cause of death due to gynecological malignancies in worldwide in 2018. ${ }^{2}$ According to the International Agency for Research on Cancer, the incidence of endometrial cancer will increase rapidly compared to 2018, and is expected to increase by more than $50 \%$ in worldwide in $2040 .{ }^{1}$ The incidence and mortality of endometrial cancer differ in worldwide. Incidence rates are generally higher in high income countries compared to low and middle income countries. ${ }^{3}$ The highest incidence rates in North America and North and Western Europe, while the lowest rates in South Asia and Africa. ${ }^{4}$ In Indonesia, the latest study found the prevalence of endometrial cancer in RSCM Jakarta reached 7.2 cases per year. From these data, endometrial cancer is rarely found in the age group under 40 years. Research at H.Adam Malik General Hospital in 2012-2015, the number of patients with endometrial cancer was found 48 cases, where the most patients found was $>55$ years old $(45.8 \%)$, followed by patients age $45-55$ years $(31.3 \%)$ and the least is patients with age $<45$ years $(22.9 \%) .{ }^{5}$

Endometrial cancer is the most common malignancy in the uterus, where the most common type is endometrioid carcinoma which accounts for $83 \%$ of cases. ${ }^{6}$ The prognosis for endometrial carcinoma is generally good if the diagnosis is found at an early stage. ${ }^{7,8}$ The survival rate of patients with endometrial cancer is related to tumor stage, depth of myometrial invasion, and histological type of tumor including tumor grading. After surgical removal of the tumor, the factors related to the prognosis are histologic grading and clinical stage which are important to determine further management decisions. ${ }^{8,9}$

Tumor budding is a histopathological feature that can be identified using routine pathological examination. Tumor budding is defined as single cells or clusters of up to four cells at the margin of the tumor front. This feature is found in various types of malignancies which send finger-like projections called buds into surrounding tissue. During localized cancer growth, some of these clusters of cells detach from the main tumor body and invade the surrounding stroma. This phenomenon is considered to be the histological basis for the formation of metastases and further tumor invasion. ${ }^{8,10}$

The clinical significance of tumor budding has begun to develop in recent years as the phenomenon of tumor budding is associated with adverse clinical outcomes. The cancer site where tumor budding has been

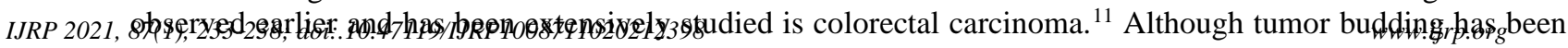


suggested as a useful prognostic marker in several tumors, research on tumor budding in endometrial carcinoma is still very limited.

\section{MATERIALS AND METHODS}

This is an analytical study with cross sectional approach on 38 samples of endometrial cancer who underwent surgery were diagnosed histopathologically with Hematoxylin Eosin (H\&E) staining in the Department of Anatomic Pathology Faculty of Medicine Universitas Sumatera Utara / H. Adam Malik Hospital Medan. The statistical analysis was performed by using Chi-square test to analyze the correlation of tumor budding index and histopathological grading in endometrial cancer.

Tumor budding is defined as single cells or clusters of up to four cells at the margin of the tumor front. ${ }^{8,10}$ The tumor budding reporting system according to the 2016 International Tumor Budding Consensus Conference (ITBCC) in colorectal carcinoma is that after determining the part with the highest tumor budding intensity from all lesions, then the tumor budding will be classified as a low budding category if 0-4 buds were found, the intermediate budding category if 5-9 buds were found, and the high budding category if 10 buds were found. ${ }^{12}$

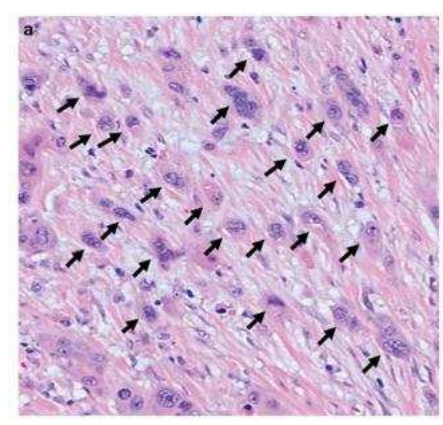

Figure 1. Tumor budding is defined as single tumor cells or tumor cell clusters at up to four cells. ${ }^{12}$

\section{RESULTS}

From this study obtained the mean age of the patient was 55,5 years with a minimum age of 31 years and a maximum of 84 years with the most common age group was > 55 years as many as 20 cases $(52,6 \%)$, followed by the $45-55$ years age group with 13 cases $(34.2 \%)$, and the least in the group age <45 years as many as 5 cases $(13,2 \%)$.

Table 1. Frequency distribution of endometrial cancer patients based on age

\begin{tabular}{|c|c|c|}
\hline Age group, mean $\pm S D$, years & $\begin{array}{c}\mathrm{N} \\
55,5 \pm 11,4 \\
\end{array}$ & $\begin{array}{c}\text { Percentage } \\
(\%)\end{array}$ \\
\hline$<45$ years & 5 & 13,2 \\
\hline $45-55$ years & 13 & 34,2 \\
\hline$>55$ years & 20 & 52,6 \\
\hline Total & 38 & 100 \\
\hline
\end{tabular}

The microscopic examination results showed that the frequency distribution of endometrial cancer patients based on the tumor budding index was the most low budding with 22 cases $(57.9 \%)$, followed by high budding as many as 9 cases $(23.7 \%)$, while for intermediate budding the least amounting to 7 cases $(18.4 \%)$.

Table 2. Frequency distribution of endometrial cancer patients based on tumor budding index

\begin{tabular}{lcc}
\hline Tumor Budding Index & $\mathrm{N}$ & Percentage $(\%)$ \\
\hline High & 9 & 23,7 \\
Intermediate & 7 & 18,4 \\
Low & 22 & 57,9 \\
\hline Total & 38 & 100 \\
\hline
\end{tabular}

Grading endometrial cancer is divided into two categories. In this study, the frequency distribution of

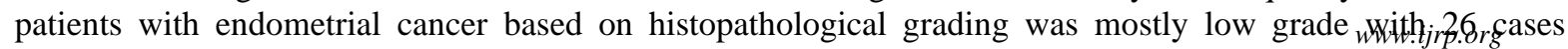


(68.4\%) compared to high grade with 12 cases $(31.6 \%)$.

Table 3. Frequency distribution of endometrial cancer patients based on histopathological grading

\begin{tabular}{lcc}
\hline Grading & $\mathrm{n}$ & Percentage(\%) \\
\hline Low grade & 26 & 68,4 \\
High grade & 12 & 31,6 \\
\hline Total & 38 & 100 \\
\hline
\end{tabular}

In this study 38 samples were examined, each sample was assessed for tumor budding index which was grouped based on histopathological grading of endometrial cancer to examine the correlation between variables. The results of statistical test analysis showed that there was a significant correlation between the tumor budding index grouped based on histopathological grading of endometrial cancer with a value of $p$ $=0.002(\mathrm{p}<0.05)$.

Table 4. The correlation of tumor budding index and histopathological grading in endometrial cancer

\begin{tabular}{|c|c|c|c|c|c|}
\hline \multirow{3}{*}{ Tumor Budding } & \multicolumn{4}{|c|}{ Grading Histopatologi } & \multirow[t]{3}{*}{ p value* } \\
\hline & \multicolumn{2}{|c|}{ Low } & \multicolumn{2}{|c|}{ High } & \\
\hline & $\mathrm{n}$ & $\%$ & $\mathrm{~N}$ & $\%$ & \\
\hline High & 2 & 22,2 & 7 & 77,8 & 0,002 \\
\hline Intermediate & 5 & 71,4 & 2 & 28,6 & \\
\hline Low & 19 & 86,4 & 3 & 13,6 & \\
\hline
\end{tabular}

*Chi square test
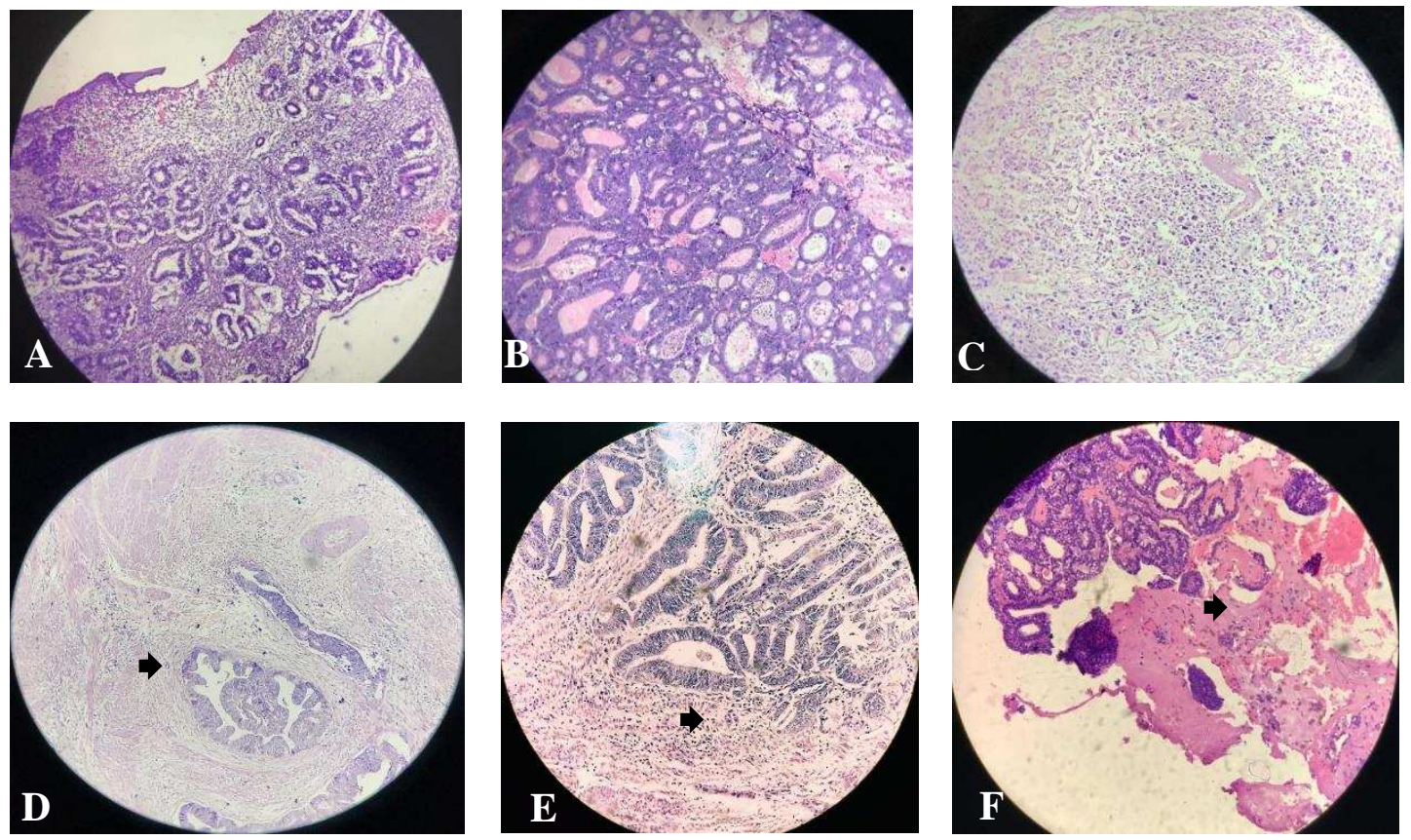

Figure 2. A. Endometrioid carcinoma FIGO grade 1 (low grade) (H\&E 100x), B. Endometrioid carcinoma FIGO grade 2 (low grade) (H\&E 100x), C. Endometrioid carcinoma FIGO grade 3 (high grade) (H\&E 100x), D Low budding (H\&E 200x), E. Intermediate budding (H\&E 200x), F. High budding (H\&E $200 x)$.

\section{DISCUSSION}

In this study, endometrial cancer patients were mostly found in the age group $>55$ years as many as 20 cases $(52.6 \%)$, followed by the $45-55$ year age group with 13 cases $(34.2 \%)$, and the least was <45 years as many as 5 cases $(13.2 \%)$. This is same result with a research by Christian at H.Adam Malik General Hospital Medan in 2012-2015 where the most patients were aged $>55$ years (45.8\%), followed by patients aged 45-55 years $(31.3 \%)$, and the least are patients aged $<45$ years $(22.9 \%) .{ }^{5}$ Research by Dewi also obtained results that

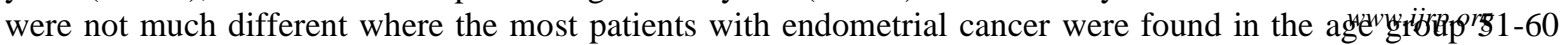


years $(46.2 \%) .{ }^{13}$ Research by Tulumang also showed results that were not much different where from 36 cases of endometrial cancer in the $2013-2015$ period, $66.7 \%$ of cases were found at the age of $>50$ years, while cases with age $<45$ years were $19.4 \% .{ }^{14}$ In accordance with the literature that the risk of endometrial cancer increases in women with advancing age, which usually occurs in postmenopausal women with high total estrogen concentrations. After menopause the ovaries stop producing the hormones progesterone and estrogen. However, small amounts of estrogen are still naturally produced in adipose tissue. Estrogen present in fat tissue has a greater effect after menopause than before menopause in terms of causing endometrial cancer. In addition, hormone replacement therapy in postmenopausal women containing estrogen without a combination with progesterone also increases the risk of endometrial cancer. Older menopausal age is also a risk due to prolonged exposure to estrogen. ${ }^{15,16}$ In addition, endometrial cancer that occurs in older women usually has a higher histopathological grade and poorer survival. ${ }^{17,18}$ In this study, the youngest age was 31 years and the oldest was 84 years. According to the literature, endometrial cancer is relatively rare in patients younger than 40 years. ${ }^{19,20}$ The incidence in young women is $2 \%-14 \%$. Endometrial cancer in this age group may be familial, associated with Lynch syndrome, or sporadic. Patients usually experience increased exposure to estrogen. Other risks include an earlier age of menarche and an unhealthy lifestyle that results in obesity. ${ }^{20,21,22,23}$ Usually the histopathological subtype at this age is low grade endometrioid carcinoma with a lower stage and is associated with a better prognosis. ${ }^{20}$

Research on tumor budding has been carried out in several malignancies where this phenomenon is considered as the histological basis for the formation of metastases and further tumor invasion. ${ }^{8,10}$ In this study, the frequency distribution of endometrial cancer patients based on the tumor budding index was low budding as many as 22 cases $(57,9 \%)$, followed by high budding as many as 9 cases $(23.7 \%)$, while for intermediate budding the least as many as 7 cases (18.4\%). In the study of Klutz et al defines tumor budding as positive if 5 buds per large field of view were found and negative if $<5$ buds per large field of view were found, where the study found positive budding tumors in $72 \%$ of endometrioid carcinoma cases and $67 \%$ of cases of nonendometrioid carcinoma compared with a negative tumor budding. ${ }^{24}$ Research by Koyuncuoglu found that the most cases of endometrial cancer found tumor budding in the low grade category, as many as $76.8 \%$ cases compared to high grade cases as many as $23.2 \%$ cases. In this study, tumor budding was categorized as low grade if $<5$ buds per large field of view were found and high grade if 5 buds per large field of view were found. ${ }^{10}$ Tumor budding is believed to be a sign of cancer cell motility and as an early step in the metastatic process which is often associated with epithelial mesenchymal transition (EMT). EMT is a transition process of epithelial cells into mesenchymal cells, in which cancer cells that are released partially or completely lose the characteristics of epithelial cells, are separated from the surrounding epithelial cells, and acquire the characteristics of mesenchymal cells so that they can migrate. ${ }^{12,24,25,26}$

The grading of endometrial cancer based on the classification according to WHO is divided into two categories, there are low grade and high grade. Included in the low grade category are endometrioid carcinoma FIGO grades 1 and 2 and mucinous carcinoma. While the high grade category is endometrioid carcinoma FIGO grade 3, serous carcinoma, clear cell carcinoma, , mixed carcinoma, and undifferentiated carcinoma. ${ }^{15,16,27}$ In this study, the frequency distribution of endometrial cancer patients based on histopathological grading was low grade as many as 26 cases $(68.4 \%)$ compared to high grade as many as 12 cases $(31.6 \%)$. This is same result with the research of Klutz et al which showed the most grading of endometrial cancer was grade 2 in $63 \%$ of cases, followed by grade 1 in $25 \%$ of cases, and grade 3 in $12 \%$ of cases. ${ }^{24}$ Research by Koyuncuoglu also obtained similar results where the highest grading was found in grade 2 as many as $37.9 \%$ cases, followed by grade 1 in $31.6 \%$ cases, and grade 3 in $30.5 \%$ cases. ${ }^{10}$ Research by Zhang et al involving 1434 cases of endometrial cancer without adenomyosis also found the highest results were found in cases which were a combination of grades 1 and 2, as many as $1212(84.52 \%)$ cases, while grade 3 cases were $222(15.48 \%)$ cases. ${ }^{28}$ Likewise with a study by El-Wahed which found that the most cases were found in grade 2 as many as $46.2 \%$ cases followed by grade 1 as many as $38.5 \%$ cases. $^{29}$ The literature says that the most common type of endometrial cancer is endometrioid carcinoma which accounted for $83 \%$ of cases where endometrioid carcinoma was classified as type I carcinoma. Type I carcinomas mostly had a low histological grade and showed a good prognosis. In contrast, type II carcinoma is less common and has a higher grade and more aggressive behavior. ${ }^{30,31}$

This study aims to analyze the correlation between tumor budding index and histopathological grading of endometrial cancer. After analyzing statistical tests with Chi-Square test, there was a significant correlation between tumor budding index and histopathological grading (p: 0.002). This is in line with the research of Kluz et al where it was found that there was a significant difference of tumor budding observed between low grade and high grade endometrial cancer. This study suggests that tumor budding can be an indicator to assess tumor aggressiveness in endometrial cancer. ${ }^{24}$ The study by Koyuncuoglu concluded that tumor budding in endometrial cancer did not achieve a statistically significant correlation to the grading of endometrial cancer. However, tumor budding is associated with undifferentiated tumor, advanced stage, and decreased postoperative survival rates. This may be a clinicopathological prognostic factor that can be applied in routine 
examinations. ${ }^{10}$

Currently, there are still differences in the assessment of the grading system in reporting tumor budding. There are those who divide it based on the three-tier grading system, but there are also those who divide it based on the two-tier grading system. ${ }^{12,26}$ However, this grading system is not an absolute standard. ${ }^{12}$ Research on tumor budding has begun to develop in recent years where the phenomenon of tumor budding is associated with with adverse clinical outcomes. Research on tumor budding has been carried out in several malignancies, like in colorectal, gastric, esophageal, lung, head and neck, and breast. ${ }^{25}$ Research on tumor budding has begun to develop in recent years where the phenomenon of tumor budding is associated with adverse clinical outcomes. ${ }^{10,12,24,25,26}$

\section{CONCLUSION}

After conducting research on 38 samples of endometrial cancer it found that the average age of patients was 55.5 years with a minimum age of 31 years and a maximum of 84 years, the most common age group was $>55$ years $(52,6 \%)$, the most frequent distribution was low budding $(57,9 \%)$, low histopathological grading $(68,4 \%)$, and there was a significant correlation between the tumor budding index and the histopathological grading in endometrial cancer where the higher tumor budding index is associated with the higher histopathlogical grading of endometrial cancer $(\mathrm{p}=0,002)$.

\section{ACKNOWLEDGEMENTS}

We acknowledge to the Department of anatomical pathology, Universitas Sumatera Utara and H.Adam Malik General Hospital, Medan, Indonesia for their help and cooperation.

\section{ETHICAL APPROVAL}

Health Research Ethical Committee. Universitas Sumatera Utara, Medan, Indonesia approved thisstudy.

\section{AUTHORS DETAILS}

dr. Devi Nafilah Yuzar, resident of Anatomical Pathology Departement, Faculty ofMedicine, Universitas Sumatera Utara, Medan, Indonesia.

Dr. dr. Betty, M.Ked (PA), Sp.PA, Lecture and staff anatomical Pathology Departement, Faculty of Medicine, Universitas Sumatera Utara, Medan, Indonesia.

dr. Jessy Chrestella, M.Ked (PA), Sp.PA, Lecture and staff anatomical Pathology Departement, Faculty of Medicine, Universitas Sumatera Utara, Medan, Indonesia.

dr. H. Soekimin, Sp.PA (K), Lecture and staff anatomical Pathology Departement, Faculty of Medicine, Universitas Sumatera Utara, Medan, Indonesia.

dr. Joko S. Lukito Sp.PA (K), Lecture and staff anatomical Pathology Departement, Faculty of Medicine, Universitas Sumatera Utara, Medan, Indonesia.

Corresponding Author-dr. Devi Nafilah Yuzar, resident of Anatomical Pathology Departement, Faculty of Medicine, Universitas Sumatera Utara, Jl. Universitas no.1 Gedung Abdul Hakim, Keruntung, Medan, Indonesia.

Emai ID: devinafilah@yahoo.co.id

\section{REFERENCES}

1. Morice P, Leary A, Creutzberg C, Abu-Rustum N, Darai E. Endometrial cancer. Lancet. (2016) 387:1094-108. doi: 10.1016/S0140-6736(15)00130-0 
2. Bray F, Ferlay J, Soerjomataram I, Siegel RL, Torre LA, Jemal A. Global cancer statistics 2018: GLOBOCAN estimates of incidence and mortality worldwide for 36 cancers in 185 countries. CA Cancer J Clin. (2018) 68:394-424. doi: 10.3322/caac. 21492

3. Torre LA, Islami F, Siegel RL, Ward EM, Jemal A. Global cancer in women: burden and trends. Cancer Epidemiol Biomarkers Prev. (2017) 26:444-57. doi: 10.1158/1055-9965.EPI-16-0858

4. Ferlay J, Soerjomataram I, Dikshit R, Eser S, Mathers C, Rebelo M, et al. Cancer incidence and mortality worldwide: sources, methods and major patterns in GLOBOCAN 2012. Int J Cancer. (2015) 136:E359-86. doi: 10.1002/ijc.29210

5. Christian J. Karakteristik Penderita Kanker Endometrium di RSUP. H. Adam Malik Medan Tahun 2012-2015. Skripsi. Universitas Sumatera Utara. 2016

6. Casey MJ, Summers GK, Crotzer D. Endometrial Cancer. [Updated 2020 Jul 13]. In: StatPearls [Internet]. Treasure Island (FL): StatPearls Publishing; 2020 Jan-. Available from: https://www.ncbi.nlm.nih.gov/books/NBK525981/

7. Torre LA, Islami F, Siegel RL, Ward EM, Jemal A. Global Cancer in Women: Burden and Trends. Cancer Epidemiol Biomarkers Prev. 2017 Apr;26(4):444-457. doi: 10.1158/1055-9965.EPI-16-0858. Epub 2017 Feb 21. PMID: 28223433.

8. Singh N, Hirschowitz L, Zaino R, Alvarado CI, Duggan MA, Ali R, et al. Pathologic Prognostic Factors in Endometrial Carcinoma (Other Than Tumor Type and Grade). Int J Gynecol Pathol. 2019;38 Suppl 1(Iss 1 Suppl 1):S93-S113. doi:10.1097/PGP.0000000000000524

9. Siegel RL, Miller KD and Jemal A: Cancer statistics, 2018. CA Cancer J Clin 68: 7-30, 2018

10. Koyuncuoglu M, Okyay E, Saatli B, Olgan S, Akin M, Saygili U. Tumor budding and E-Cadherin expression in endometrial carcinoma: are they prognostic factors in endometrial cancer?. Gynecol Oncol. 2012;125(1):208-213. doi:10.1016/j.ygyno.2011.12.433

11. Lino-Silva LS, Salcedo-Hernández RA, Gamboa-Domínguez A. Tumour budding in rectal cancer. A comprehensive review. Contemp Oncol (Pozn). 2018;22(2):61-74. doi:10.5114/wo.2018.77043

12. Lugli A, Kirsch R, Ajioka Y, Bosman F, Cathomas G, Dawson H, et al. Recommendations for reporting tumor budding in colorectal cancer based on the International Tumor Budding Consensus Conference (ITBCC) 2016. Mod Pathol. 2017 Sep;30(9):1299-1311. doi: 10.1038/modpathol.2017.46. Epub 2017 May 26. PMID: 28548122

13. Dewi PPP, Budiana ING. Profil Pasien Kanker Endometrium di RSUP Sanglah Denpasar Periode Agustus 2012 - Juli 2014. Medika. 2017; 6 (8): 1-7

14. Tulumang JA, Loho MF, Mamengko LM. Gambaran kanker endometrium yang dirawat di RSUP Prof. Dr. R. D. Kandou Manado periode 2013-2015. eCl. 2016; 4 (1): 1-6

15. Zaino R, Carinelli SG, Ellenson LH, Eng C, Katabuchi H, Konishi I, et al. Endometrial carcinoma. In Kurman RJ, Carcangiu ML, Herrington CS, Young RH. WHO classification of Tumours of Female Reproductive Organs.Lyon. 2014; p.126 - 33.

16. Mutter GL, Guiu XM, Lax SF. Endometrial Adenocarcinoma. In Robboy SJ, Mutter GL, Prat J, Bentley RC, Russel P, Anderson MC. Robboy's Pathology of the Female Reproductive Tract $2^{\text {nd }}$ Ed. Churchill Livingstone Elsevier. 2009 ; p. 393 - 422.

17. Koual M, Ngo C, Girault A, Lécuru F, Bats AS. Endometrial cancer in the elderly: does age influence surgical treatments, outcomes, and prognosis? Menopause. 2018 Sep;25(9):968-976. doi: 10.1097/GME.0000000000001119. PMID: 29762198.

18. Bishop EA, Java JJ, Moore KN, Walker JL. Pathologic and Treatment Outcomes Among a Geriatric Population of Endometrial Cancer Patients: An NRG Oncology/Gynecologic Oncology Group Ancillary Data Analysis of LAP2. Int J Gynecol Cancer. 2017;27(4):730-737. doi:10.1097/IGC.0000000000000947

19. Son J, Carr C, Yao M, Radeva M, Priyadarshini A, Marquad J, et al. Endometrial cancer in young women: prognostic factors and treatment outcomes in women aged $\leq 40$ years. International Journal of Gynecologic Cancer 2020;30:631-639

20. Lekhi A, Manchanda R, Jain N, Chithra S, Kausar H. Endometrial carcinoma in young women: management options and its review. International Journal of Reproduction, Contraception, Obstetrics and Gynecology. 2016. 5(4), 944-947. doi:http://dx.doi.org/10.18203/2320-1770.ijrcog20160674

21. Constantine GD, Kessler G, Graham S, Goldstein SR. Increased Incidence of Endometrial Cancer Following the Women's Health Initiative: An Assessment of Risk Factors. J Womens Health (Larchmt). 2019;28(2):237-243. doi:10.1089/jwh.2018.6956

22. Raglan O, Kalliala I, Markozannes G, Cividini S, Gunter MJ, Nautiyal J, et al. Risk factors for endometrial cancer: An umbrella review of the literature. Int J Cancer. 2019 Oct 1;145(7):1719-1730. doi: 10.1002/ijc.31961. Epub 2019 Feb 20. PMID: 30387875.

23. Ghanbari Andarieh M, Agajani Delavar M, Moslemi D, Esmaeilzadeh S. Risk Factors for Endometrial Cancer: Results from a Hospital-Based Case-Control Study. Asian Pac J Cancer Prev. 2016;17(10):4791-4796. Published 2016 Oct 1. doi:10.22034/apjcp.2016.17.10.4791

24. Kluz T, Łoziński T, Czekierdowska S, Stachowicz N, Gurynowicz G, Chróściel M, et al. Tumor budding index and microvessel density assessment in patients with endometrial cancer: A pilot study. Oncol Lett. 2020;20(3):2701-2710. doi:10.3892/ol.2020.11811

25. Voutsadakis IA. Prognostic role of tumor budding in breast cancer. World J Exp Med. 2018;8(2):12-17. Published 2018 Sep 7. doi:10.5493/wjem.v8.i2.12

26. Kim BH, Kim JM, Kang GH, Chang HJ, Kang DW, Kim JH, et al. Standardized Pathology Report for Colorectal Cancer, 2nd Edition. J Pathol Transl Med. 2020;54(1):1-19. doi:10.4132/jptm.2019.09.28

27. Ellenson LH, Ronnett BM, Soslow RA, Zaino RJ, Kurman RJ. Endometrial Carcinoma. In: Kurman RJ, Ellenson LH. Blaustein's Pathology of Female Genital Tract. $6^{\text {th }}$ ed. NY: LLC; 2011. P.394-452.

28. Zhang Z, Yang B, Zhang W, Gao X, Zhao C, Zhang X, et al. Clinicopathological characteristics and survival outcomes of patients with coexistence of adenomyosis and endometrial carcinoma. Int J Clin Exp Pathol. 2018;11(2):956-962. Published 2018 Feb 1.

29. El-Wahed MMA, Abdou AG, AL-Sharaky DR, Kasem HA. Clinicopathological differences between type I and type II endometrial carcinoma. Menoufia Medical Journal. 2017;30 (3): 946-51

30. Akhtar M, Al Hyassat S, Elaiwy O, Rashid S, Al-Nabet ADMH. Classification of Endometrial Carcinoma: New Perspectives Beyond Morphology. Adv Anat Pathol. 2019 Nov;26(6):421-427. doi: 10.1097/PAP.0000000000000251. PMID: 31567131.

31. Lax SF. Pathology of Endometrial Carcinoma. Adv Exp Med Biol. 2017;943:75-96. doi:10.1007/978-3-319-43139-0_3 